The Geographical Journal of Nepal

Vol. 14: 131-150, 2021

DOI: https://doi.org/10.3126/gjn.v14i0.35556

Central Department of Geography,

Tribhuvan University, Kathmandu, Nepal

\title{
Impact of vegetable farming on farmers livelihood patterns in Dhankuta, Nepal
}

\author{
Kishor Bhandari ${ }^{1}$, and Basanta Paudel ${ }^{2 *}$ \\ ${ }^{1}$ Jalapa Devi Campus, Tribhuvan University, Pakhribas, Dhankuta, Nepal. \\ ${ }^{2}$ Geo Planet Research Centre, Kathmandu 44619, Nepal. \\ "Corresponding author: basantapaude111@gmail.com \\ Received: 04 October, 2020; Accepted: 01 December, 2020; Published: March 2021
}

\begin{abstract}
This paper deals with the livelihood pattern and the socio-economic condition of vegetable farmers of Chhathar Jorpati rural municipality, which lies in the eastern part of Dhankuta district of Nepal. The study applied household questionnaire survey, focus group discussion and field observation to collect information of vegetable farming and the impact of vegetable farming on farmers' livelihood. The study conducted 45 households questionnaire survey in total using simple random sampling in ward number six of Chhathar Jorpati rural municipality. The statistical analysis of collected field survey data was preformed through correlation test and standard deviation. The result shows that the socio-economic condition and the livelihood of the vegetable farmers is improving in recent years. Before doing commercial vegetable farming, farmers cultivated potatoes and used to exchange their production with cereal crops to the neighboring villages. Farmers used to cultivate maize in their farmland, but due to the climatic and the topographic condition it took almost nine months (from January to October) for production. Among the total households, 24.4 percent farmers have seven members in their family and the average family size is 6.3. The Chhetri is the dominant ethnic group of the study area. Among educated groups, the majorities have completed secondary level of education. Most of the farmers are (35.5\%) holding land size between 16 and 20 Ropani (0.82-0.10ha.). The majorities of the farmers cultivated high valued vegetables i. e., cauliflower, cabbage, tomato, pea, radish, carrot and green leafy vegetables. The average income from vegetable farming is NRs. 250000/household per year. Primarily, farmers use their income to manage foods, clothes, children education and daily-required goods. Further, due to the lack of sufficient human resources, improved seeds and fertilizer, the majorities of the farmers are facing challenges in
\end{abstract}


Kishor Bhandari, and Basanta Paudel/ Impact of vegetable farming ...Vol. 14: 131-150, 2021

their vegetable farming. In addition to this, the vegetable farmers are utilizing their capabilities and are devoted to enhance their livelihood through vegetable farming.

Keywords: Vegetable farming, livelihood, market, fertilizer, improved seed

\section{Introduction}

Farming is the activity or business of growing crops and raising livestock (Shaikh, 2017). Farming system is the organization of the farm and all the enterprises in relationship to each other; and it is widely differing resource based, enterprise patterns, household livelihoods and constraints (Giller, 2014). Farming is growing crops or keeping animals by people for food and raw materials. It is an integrated land based activity. Farming sector and its actors are much influenced by the spatial variation because of the need to stay contact with the market and other services (Bhatta, 2010). It is the complex arrangement of several components such as land, labor, livestock, market; and other resources that household mobilize for production in accordance with the household's preference, capabilities and available technologies in the existing environmental (biophysical and socio-cultural) setting (Shaner et al., 1981; Turner \& Brush, 1987). Any methods of farming may be seen as an integral part of an agriculture system. Agriculture is the most comprehensive word used to denote the many ways in which crop plants and domestic animals sustain the global human population by providing food and other products (David et al., 2014). The process of producing food, feed, fiber; and other desired product by the cultivation of certain plants and the raising of domestic animals or livestock (Mckenzie, 2005). Agriculture 'inputs' include the seeds, water, pesticides, herbicides, fertilizer, and the livestock which are introduced to the 'plant': the building, machinery, and land; and the 'output' is the produce of the form (Ganesan et al., 2017).

From the beginning of human civilization, agriculture has become the main source of people's livelihood. However, the term livelihood can be used in many different ways. A livelihood in its simplest sense is a means of gaining a living. Livelihood patterns are changing rapidly in the world with respect to time and space. A livelihood comprises the capabilities, assets (including both material and social resources) and activities required for a means of living. A livelihood is sustainable when it can cope with and recover from stress and shocks and maintain or enhance its capabilities and assets both now and in the future, while not undermining the natural resource base (Carney 1998). Livelihood strategies include how people combine their income generating activities; the way in which they use their assets; which assets they chose to invest in; and how they manage to preserve existing assets and income (Chambers and Conway, 1991). By following different activities and strategies people want to spend their life in a sustainable way. 
The history and development of agriculture is intimately related to the development of human civilization. Agriculture is the main sector, which fulfils the demand of hunger of growing population (OECD/FAO 2019). Agriculture is an important source of income and the world's largest business; one-third of the economically active population obtains its livelihood from agriculture (GA, 2019). Vegetable is the main source of minerals, vitamins and protein, which are the most important constituents of human diet. Vegetables supply essential micro-nutrient in human nutrition that acts as preventive agents to several ailments. Increased vegetable production may improve food security and offer employment opportunities to the populace, especially women who form a substantial proportion (Mlozi, 2003). In order to fulfill the demand of such nutrients commercial vegetable farming is increasing. Vegetables are considered very important crops both from the point of food and economic value in providing cheap source of nutrients and vitamins. At the same time, they are also considered as a high valued cash crops as they provide almost 5 to 10 times higher economic value (Gurung et al., 2016).

Agriculture is one of the major sectors of Nepalese economy (Paudel et al., 2019). There is 60.4 percent of the total population involved in this sector and contributes about 27 percent in the GDP (NPC, 2019). Agriculture in Nepal is labor intensive and farmers use their family labor in agricultural activities. Vegetable farming is a traditional custom in the Nepalese community, particularly for culinary purpose. Vegetable is the most important short seasonal and major components of Nepalese agricultural system. Because of the cash crop nature farmers pay their attention towards the commercial vegetable farming. Vegetable crop is an integral part of the farming system in Nepal and the sector has been growing rapidly in recent years (CASA, 2020). The area of vegetable farming has been continuously increasing since 1991/92 in Nepal and the production of vegetable is increasing at faster rate than increment in area (Pandey, et al. 2017). It is necessary to grow cash crops for income generation and better livelihood (Amatya, 1975). Till the mid-March of the fiscal year 2018/19, the food and livestock exports have declined by 9.9 percent and Rs.12.67 billion compared to the export during the fiscal year 2017/18; and this period, exports of oil and fat based on vegetable and animal product has been increased to Rs.5.8 billion (MOF, 2019). Now, there are different pocket areas declared by the government to get more benefit from vegetable farming in Nepal.

The farming system, production and productivity differ from place to place and season to season depending upon the terrain of the country ranging from the Tarai, the Hill and the Mountain. People of each and every pocket area have been taking different livelihood strategies. Being a rural area in Chhathar Jorpati rural municipality, the people have been adopting their own livelihood strategy by utilizing their capital assets and local resources of the area. Agricultural production is famous in this area and the 
large numbers of people are involved in agricultural activities particularly in commercial vegetable farming. Production of the vegetable from this area is being supplied to the international market like India and Bangladesh. Many researchers and scholars have paid their attention towards agriculture, livelihood strategy, and economic condition of other area but there are limited researches in Chhathar Jorpati rural municipality from the perspective of livelihood. In this context the present research seeks to understand the livelihood patterns of vegetable farmers of the hill area particularly to evaluate the strength of the farmers involved in agricultural practices. Therefore, this study evaluates the scenario of changing farming system of the study area. It will be an important guideline for the policy makers and fruitful for the planners to formulate future plans to promote people's livelihood and livelihood strategies in the rural areas.

\section{Methods and materials}

\section{The study area}

Chhathar Jorpati rural municipality is well-known as the area of commercial vegetable farming and milk production in Dhankuta district. On the basis of some major characteristics, this area has been selected as the study site. First, it is the highly occupied with the commercial vegetable farmers. Second, the vegetable farmers have been improving their livelihood due to the intensive commercial vegetable farming. This study site lies in the eastern part of the district. This rural municipality is ranging from 296 meter to 2645 meter above mean sea level. The total area of Chhathar Jorpati rural municipality is 103.5 square kilometer (Khanal et al., 2018). The total households are 4232 and the total population of the rural municipality is 18322 where male population is 8346; and female is 9976 as of census report of Nepal 2011 (CBS, 2011). There are total six wards in this rural municipality and ward number six was selected for the study area. The given figure 1 shows the location, altitudinal variation and the land use patterns of the study area. 


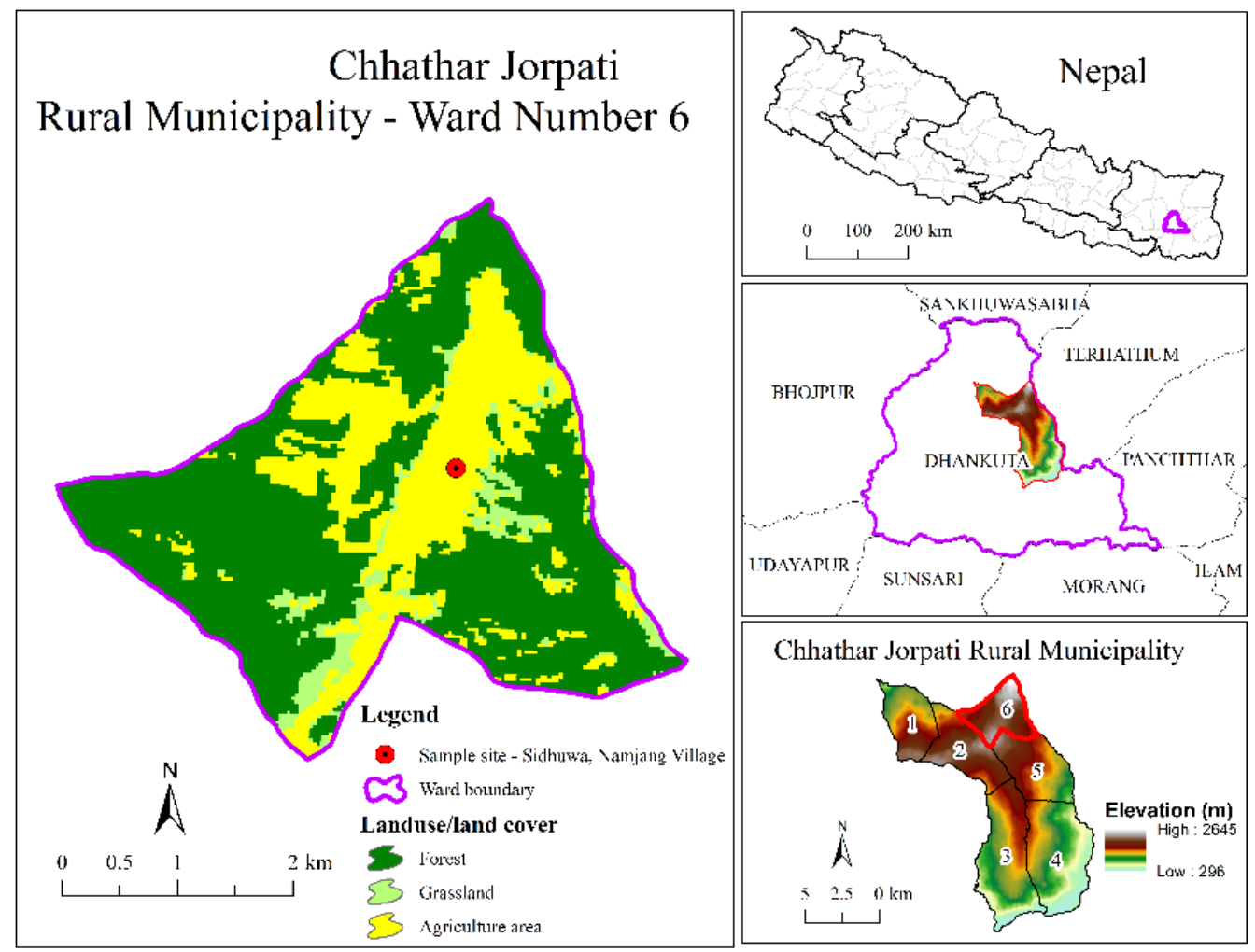

Figure 1: Location of the study area

\section{Sources of data}

This study is based on both qualitative and quantitative data. The primary data were collected from the field survey through questionnaires, focus group discussion and observation. Before conducting the field, a reconnaissance survey was conducted to get information about the areas as well as vegetable farmers. The questionnaire survey was used to generate data of the detail information about the livelihood aspect of the vegetable farmers, i. e. socio-economic condition of the farmers, income and expenditure. Further, two focus group discussion have been conducted with local farmers to get details information about vegetable farming in the study site. The secondary data were gathered from the 15th periodic plan, National Planning Commission and various publications of Central Bureau of Statistics. Land use land cover data of the study area have been adapted from Uddin et al (2015). 


\section{Data analysis and tools}

After completing the field survey, the task of data processing was done. All the completed questionnaires were transformed to the data code sheet. The tabulated data were processed and analyzed based on its results. The location map of the study area was generated using ArcGIS 10.5 (Environmental Systems Research Institute, Redlands, CA, USA). Correlation analysis was done between the education level of the respondents and the income level of the households by using the equation 1 .

$$
r=\frac{n(\Sigma x y)-(\Sigma x)(\Sigma y)}{\sqrt{\left[n \Sigma x^{2}-(\Sigma x)^{2}\right]}\left[n \Sigma y^{2}-(\Sigma y)^{2}\right]}
$$

where, $r$ is the correlation coefficient between education level of the male respondents and the female respondents; $\mathrm{x}$ indicates the education level of the male respondents and $y$ indicates the education level of the female respondents. Simple mean was also calculated in order to find out the average family size of the study area. Likewise, standard deviation was calculated to analyze land holding pattern by using the equation 2 .

$$
\sigma=\sqrt{ } \sum f x^{2} / \mathrm{N}
$$

where, $\sigma$ is standard deviation, $f$ is the number of the households in different categories (frequency), $x^{2}$ is the squire of difference between the land holding status and the mean value of the land holding size; and $\mathrm{N}$ is the total number of households of the study area.

\section{Results and discussion}

\section{Social condition of the vegetable farmers}

Major social condition in this section includes age and sex composition; family size and household population, caste/ethnic status; and level of education of the study. The concept of social status or social condition has two primary usages. One is a person's position in the pattern of social relations among members of the social system. The next one is a person's status evaluative ordering of members in regard to honor or prestige (Fararo, 2007). Therefore, the social status is in all socio-economic studies are very important. 


\section{Age and sex composition of the vegetable farmer households}

The age group of the family members' shows the likelihood of the age group in the productive age as well as non-productive age group in the family. The total population of the 45 households is 283 . Where the male population is 46.6 percent and the female is 53.4 percent. The sex ratio is 87.42 in the study area; and the sex ratio of Nepal in 2011 is 94.2 (CBS, 2011). According to the national data, the sex ratio of Dhankuta district in 2011 is 88.1 which is quite similar to the study area. The highest number of population in terms of age group is 71 within 21-30 years age group whereas the age group of 51-60 years is found to be the lowest number (Table 1). Active population of the study area is less than the overall country data according to the census data 2011. The old population above 60 years is 10.9 percent in the study area which is higher than the overall country data $(8.14 \%)$.

Table 1: Age and sex composition of family members of vegetable farmer households

\begin{tabular}{|c|r|r|r|r|r|r|}
\hline Age Group & Male & Percentage & Female & Percentage & Total & Percentage \\
\hline$<10$ Years & 30 & 10.6 & 40 & 14.2 & 70. & 24.8 \\
\hline $11-20$ & 27 & 9.5 & 26 & 9.2 & 53 & 18.7 \\
\hline $21-30$ & 33 & 11.7 & 38 & 13.4 & 71 & 25.1 \\
\hline $31-40$ & 14 & 4.9 & 15 & 5.3 & 29 & 10.2 \\
\hline $41-50$ & 9 & 3.2 & 12 & 4.2 & 21 & 7.4 \\
\hline $51-60$ & 5 & 1.8 & 3 & 1.1 & 8 & 2.9 \\
\hline $61-70$ & 8 & 2.8 & 7 & 2.5 & 15 & 5.3 \\
\hline$>70$ & 6 & 2.1 & 10 & 3.5 & 16 & 5.6 \\
\hline Total & 132 & 46.6 & 151 & 53.4 & 283 & 100 \\
\hline
\end{tabular}

Source: Field Survey, 2019.

\section{Family size and the household population}

The family size is an important in respect to the person available for field-work and participation in vegetable farming because vegetable farming is labor intensive work. The study carried in Kirtipur area of Kathmandu by Rai (2017) found that the participation of women in vegetable production is essential. This work allows women to be self-sufficient, independent, increases their capabilities and improves their social status in their families and communities. Women's role is important for the different activities of vegetable farming; planting, weeding, collecting and selling. In this study of Chhathar Jorpati among the total 45 sampled households, majority of the families have 7 members. There is a family where 12 members live together; which is the largest size family of this area. There are 9 households having the family size of 4 members. 
There are 3 to 12 members in the families (Table 2). More than 50 percent households have less than 6 members. The average family size of the study area is 6.3 .

Table 2: Family size of vegetable farmers household

\begin{tabular}{|c|r|r|}
\hline No. of Family Member & No. of Households & \multicolumn{1}{|c|}{ Percentage } \\
\hline 3 & 3 & 6.7 \\
\hline 4 & 9 & 20.0 \\
\hline 5 & 8 & 17.9 \\
\hline 6 & 6 & 13.3 \\
\hline 7 & 11 & 24.4 \\
\hline 8 & 2 & 4.4 \\
\hline 9 & 1 & 2.2 \\
\hline 10 & 3 & 6.7 \\
\hline 11 & 1 & 2.2 \\
\hline 12 & 1 & 2.2 \\
\hline Total & 45 & 100 \\
\hline
\end{tabular}

Source: Field Survey, 2019.

\section{Caste/Ethnic composition of the vegetable farmers}

Ethnicity is a social component of population. It reflects socio-cultural characteristics of the population. According to the census report of 2011, there are 125 ethnic groups found in Nepal. The Chhathar Jorpati rural municipality is not diverse in terms of ethnicity. There are only six castes found in the study area. Chhetri dominated this area; where among 45 households 33 are Chhetries. Among 33 Chhetri households Thapa, Bista and Basnet households are found 18,12 and 3, respectively. According to the census data of 2011 the population of Chhetries is 16.6 percent, which is the highest percent among all ethnic groups. There are 4 and 3 households of Newar and Limbu respectively. In the study of livelihood strategy of Rai community in two different location representing different altitudinal zone in Arun Valley, namely Sitalpati and Makalu, Subedi and Pandey (2002) revealed that land utilization pattern was changed from Bari (non-irrigated land) towards Khet (irrigated land) in lower elevated area and changed from Khoria (slash and burn) to Bari (non-irrigated land) in higher elevated area. This study illustrated that how people's response to environmental and economic pressure can differ in two different environments. Although the caste and ethnicity background is different the finding of both studies is similar in terms of land resource utilization. 


\section{Level of education of the respondents}

Education plays a vital role in the socio-economic development of the society. Educated persons can easily take any decision quicker and better than uneducated persons. In the study out of 45 respondents, 29 respondents feel education is important for the better knowledge of vegetable cultivation. The positive aspect of education is that the farmers give their introduction as a farmer without any hesitation. Educated farmers respect their work. There are 18 male and 27 female respondents in the study. In the comparison of male and female respondents, the level of education of the male is better than the female. The literate and illiterate percentage of the respondents in both sex groups is 77.8 and 22.2, respectively (Table 3). Among the educated groups, larger numbers (29\%) completed secondary level of education. Only 7.76 percent of the people passed secondary level in the overall country (CBS, 2011). The average literacy rate of the study area is more than the national data. Among the 45 respondent farmers only one male has passed bachelor level. According to the calculation of correlation between the male education and the female education level, there is a positive correlation between these two variables. The result of the correlation between these two variables is 0.044 .

Table 3: Level of education of household heads

\begin{tabular}{|l|l|l|l|l|l|l|}
\hline \multirow{2}{*}{ Educational Status } & \multicolumn{3}{l|}{ Male } & Female & Total \\
\cline { 2 - 7 } & No. & Percentage & No. & Percentage & No. & Percentage \\
\hline Illiterate & 0 & 0.0 & 10 & 37.1 & 10 & 22.2 \\
\hline Literate & 6 & 33.34 & 4 & 14.8 & 10 & 22.2 \\
\hline Primary & 3 & 16.63 & 4 & 14.8 & 7 & 15.6 \\
\hline Secondary & 6 & 33.34 & 7 & 25.9 & 13 & 29 \\
\hline Higher Secondary & 2 & 11.12 & 2 & 7.4 & 4 & 8.8 \\
\hline Bachelor & 1 & 5.57 & 0 & 0.0 & 1 & 2.2 \\
\hline Total & 18 & 100 & 27 & 100 & 45 & 100 \\
\hline
\end{tabular}

Source: Field Survey, 2019.

\section{Economic condition and the livelihood patterns of the vegetable farmers}

'Struggle for existence' as envisaged by Darwin is still regarded as the central concept of livelihood strategy. Anyone, who cannot adjust himself/herself in a changing environment, cannot survive in this Earth. Being a social creature, human should perform group activities to do struggle with the natural change as well as with different natural calamities. Because of the introduction of modern technology, human has brought tremendous change in the use of natural resources. But in the context of the farmers of Chhathar Jorpati, they have been using their local resources in traditional way for their livelihood. 
The people of this area are changing their way of life due to the development of road and electricity facilities. Almost all households have given the top priority in vegetable farming. Vegetables like cabbage, cauliflower, radish, bean and pea, chilly and green leafy vegetable are grown in this area. Cereal crop production gets second priority. Some farmers grow cereal crop for subsistence needs only. It was found that after the construction of road and the supply of electricity facility have drastically changed in the livestock keeping, services, business and industry etc. Different types of cooperative institutions such as saving and credit, milk collection, consumer etc. are supporting commercial agriculture in the study area. As a result, the livelihood patterns of the farmers in different parts have been changed from subsistence farming to commercial vegetable farming (Rai et al., 2019a in Kathmandu; Chapagain, 2006 in Ilam).

There was different conclusion in the study of livelihood strategies of people living in Karnali region. Karnali, being located in the northern Himalayan region and having rugged terrain, low productivity and no accessibility in terms of road connectivity bears very hard circumstance for the people to seek their livelihood (Bishop, 1990). Livestock ranching is the most important activity characterized by seasonal movement to higher elevation areas in summer to lower areas in winter. Due to lower temperature in long winter season, agricultural activities require long growing season. Lack of diversification of livelihood activities in the area is very common. Therefore, the researcher advocates for the need of more activities to strengthen the livelihoods of the people that enables them to improve their livelihood security. The situation of Chhathar Jorpati rural municipality is different because of road access and good educational status. Therefore, they are able to adopt vegetable based livelihood strategy.

Mountain environment is changing perceptibly in their natural and economic setting. Bringing example from southern Arun Valley, Koirala (2006) has undertaken spatiotemporal analysis of resource utilization since 1984 to 2004. According to the study, the major livelihood strategies included agro based activities characterized by several distinct types such as cereal crop farming, horticulture, cash crop farming. Better connectivity of the road changed traditional food crop production to horticulture and cash crops; and has helped to improve household income. The result of the study done by Koirala and the situation of the vegetable farmers of Chhathar Jorpati is both similar.

\section{Land holding pattern of the vegetable farmer}

Land holding is also the major component for the vegetable production. Production depends upon the size and the types of available land. The agrarian structures in Nepal are characterized by a very small land holding scattered to different plots. As an agrarian 
economic country such as Nepal, land ownership is the most important source of food security and household income as land being the important economic assets in the rural area (Gauchan, 2008). There is no problem of land for vegetable farming in this rural area. Among 45 households, $35.5 \%$ possesses 16 - 20 Ropani of land. Likewise, five households have more than 30 Ropani land but they do not utilize all land to grow vegetable. Thus, only three households have less than 5 Ropani land. According to the data of CBS 2011, small landholders and marginal farmers predominate in Nepalese agriculture with the average holding size of 0.8 hector. Nearly half of all farms have less than 0.5 hectare (less than ten Ropani) of land. In the study area, only 15.6 percent of the farmers have less than 10 Ropani land (Table 4). Likewise, land tenure system also plays a vital role in agriculture production; dual land tenure has been hampering for agriculture development. With the comparison of the national data the situation of land holding pattern of the vegetable farmers is better. The standard deviation of land holding pattern data is 7.95 . It shows that there is no vast difference among farmers in terms of land holding pattern.

Table 4: Land holding pattern

\begin{tabular}{|c|r|r|}
\hline Land (In Ropani) & No. of Households & \multicolumn{1}{|c|}{ Percentage } \\
\hline Below 5 & 3 & 6.7 \\
\hline $6-10$ & 4 & 8.9 \\
\hline $11-15$ & 10 & 22.2 \\
\hline $16-20$ & 16 & 35.5 \\
\hline $21-25$ & 4 & 8.9 \\
\hline $26-30$ & 3 & 6.7 \\
\hline Above 30 & 5 & 11.1 \\
\hline Total & 45 & 100 \\
\hline
\end{tabular}

Source: Field Survey, 2019.

\section{Annual Income from vegetable farming occupation}

All vegetable farmers do not have equal access to land, labor, capital and other opportunities. As a result the socio-economic status is not the same. In 2015, vegetable worth of NRs. 370 million was sold from Sidhuwa Agriculture Store, Chhathar Jorpati Rural Municipality, Dhankuta (Gahatraj, et al., 2019). According to his study, out of the sold vegetables cabbage had the largest shares of 2500 tons. The study found that within Chhathar Jorpati Rural Municipality, majority of (16 vegetable farmers) households are earning NRs. $100000-200000$ in a year. 


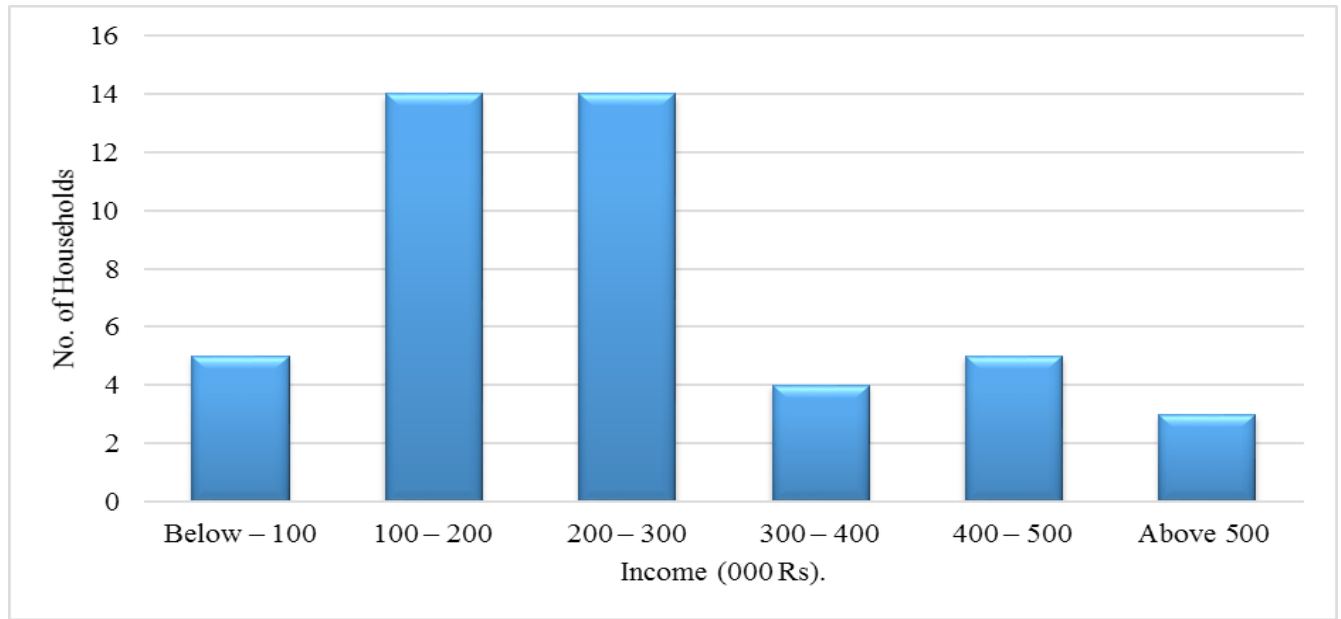

Figure 2: Annual income from vegetable farming occupation.

The yearly average income of vegetable farmers is NRs. 247000. Most households earn between Rs.100000-300000 annually. Only 5 households earn less than Rs.100000 annually (Figure 2). The study on vegetable farming and farmers' livelihood in Kathmandu Valley by Rai et al. (2019a) also found minimum earning of a vegetable farmer ranging from NRs.50,000 to NRs.500,000 which is similar to the annual income of vegetable farmers of Chhathar Jorpati municipality as well.

A study on the garden pea production and financial profitability of Chhathar Jorpati rural municipality and Mahalaxmi municipality was done by Gahatraj and Uprety, (2019). In the study, they found that the garden pea production is the most important source of income of the farmers of the study area. In another study on the same area, the finding was that the vegetable had a significant contribution in the total income of the farmers; while cabbage was a major contributor (Gahatraj et al., 2019). These studies also prove that the vegetable farming is the profitable occupation in Chhathar Jorpati area.

\section{Utilization of vegetable income}

Primarily, farmers are utilizing their income in food, clothes, children education and daily required goods. These are common sectors of expenditure. As their earning increased, they utilize it in other sectors, such as in purchasing cultivated land, improving the housing conditions, building toilet and in other luxury things. The survey revealed that food, clothing, and the daily use; and education activities are the common areas of expenditure of all vegetable farmers. All vegetable farmers are conscious to their 
children's education and they realize that education is an integral part of the social life. Of the total 45 households 82.2 percent utilized their income in additional social functions, improvement of the housing condition, health and sanitation. Here, social function means economic participation in social activities such as temple construction, rural road construction, donation to the school etc. Health and sanitation include checking up at the time of illness, spending money to buy medicine, to make toilet etc. Of the total 44.4 percent farmers utilize the income in land purchase for cultivation; 33 percent farmers use this income to both livestock purchase and bank balance; and 11 percent farmers invest to purchase land in urban area (Table 5).

Table 5: Utilization of vegetable income

\begin{tabular}{|l|r|r|}
\hline Area of Expenditure & No. of Household & Percentage \\
\hline Food and daily use goods & 45 & 100 \\
\hline Land purchase for cultivation & 20 & 44.4 \\
\hline House construction / improvement & 37 & 82.2 \\
\hline Health and sanitation & 37 & 82.2 \\
\hline Children education & 45 & 100 \\
\hline Land purchase in urban area & 5 & 11.1 \\
\hline Bank balance & 15 & 33.3 \\
\hline Livestock purchase & 15 & 33.3 \\
\hline Social function & 20 & 44.4 \\
\hline
\end{tabular}

Source: Field Survey, 2019.

\section{Impact of the commercial agriculture farming}

\section{Positive impact}

Vegetable is considered to be a very important crop both from the point of food and economic value in providing cheap source of nutrients and vitamins. Demand of quality vegetable is going to increase so the attraction of farmers goes towards the vegetable farming. Before doing commercial vegetable farming, people of Chhathar Jorpati rural municipality produced potatoes and they used to exchange their production with cereal crop to the neighboring villages. They used to give double units of potatoes for a single unit of paddy. They used to grow maize in their land but it took about nine months (from January to September) to prepare. On the other hand, the productivity was very low. A project lunched through Sindhuwa Multipurpose Cooperative Limited inspired to do commercial vegetable farming in 2051 B.S. There were different programs in the project i.e. small group making program, vitamin A program, seed distribution \& awareness program etc. The project was launched with the joint association of Pakhribas 
Agriculture Centre. People were being shifted towards commercial vegetable farming gradually. Now, this area produces about 20 trucks vegetable per day. One to two truck vegetable is being consumed in Nepal and the rest of vegetable is being supplied to India and Bangladesh. The vegetable farmers of Chhathar Jorpati area have changed meadow and pasture land into agriculture land and they are farming vegetable which is as similar as the findings of Shrestha (1975) on land use change.

Because of increasing income rate of the farmers, they are now able to get quality health and education facility. The great achievement is that the farmers are succeeding to break up the traditional culture to see farming as a low level occupation in the society. The farmers do not hesitate to give their identity proudly as farmer. They are now becoming united in different cooperatives. So they have developed the concept of institutional development. According to the three interlink concepts for sustainable livelihood namely capability, equity and sustainability, the vegetable farmers are able to build up their capability by farming experience and different training. Likewise there is not any restriction of doing vegetable farming, so they have equal access to the resources as a result they are able to sustain their lives.

In the study of Kaski and Kapilvastu districts on the basis of commercial vegetable farming for poverty reduction in Nepa1, Gurung et al. (2016) concluded that there has been a significant improvement in the production of vegetables after ten years in both the studied area. The result clearly shows that there was a continuous production and supply of vegetables from the farms and which indicates that farmers are shifting towards commercialization. Commercial vegetable farming is fruitful for poverty reduction in the study area. The situation of the vegetable farmers of Chhathar Jorpati rural area is not an exception to it.

\section{Negative impact}

Human empowerment is an important aspect of livelihood. Education plays a vital role to be empowered. In Chhathar Jorpati rural area, farmers start their occupation before they complete education. Therefore, the educational status is low. Because of the low level of educational status, the rural area may be lagging behind in the human development index. All farmers are not conscious to the protection of their environment. As a result, environment will be polluted in future. Because of the busy life, it is very difficult for them to give time for social work as well. 


\section{Problems associated with the commercial vegetable farming}

Definitely, every occupation has some sorts of problems. Different types of diseases and shortage of marketing are common and major problems of vegetable farming. Most of the commercial vegetable growing areas of Chhathar Jorpati rural municipality have been already infested by Clubroot Pathogen (Plasmodiophora brassicae). Productivity has been drastically reduced for few years after field got infested with Pathogen (Gahatraj et al., 2019). Karkee et al. (2016) found that Clubroot Pathogen has been emerged as one of the most harmful diseases of cabbage and cauliflower in Dhankuta and Terathum. In the study of the commercial vegetable farming in Kirtipur, Rai et al. (2019b) observed that frequent price fluctuation of market price was the first major problem, and high margin of profit taken by middlemen was another crucial constraint in commercial vegetable farming. The disease in vegetable is also notable. The study of Ellis (1999) on poverty, land care and sustainable livelihoods in hillside and mountain region concluded that the area are particularly vulnerable for livelihood due to their inaccessibility, fragility, marginality and land degradation. In an comparative study of of farm in Kavrepalanchok, Sindhupalchok and Kaski districts, Pokhrel (2010) found diseases and pests severities, fluctuating prices, deteriorating soil environment, lack of year-round irrigation and poor quality of seed and fertilizer materials as well as the poor marketing facilities to hinder vegetable farmers from optimum benefits. The problems in Chhathar Jorpati area are not an exception from the problems of the farmers of other areas of Nepal (Table 6).

Table 6: Problems of the commercial vegetable farming

\begin{tabular}{|c|c|c|}
\hline General Problems & & Specific problems \\
\hline $\begin{array}{l}\text { Market related } \\
\text { problems }\end{array}$ & $\begin{array}{l}\square \\
\square\end{array}$ & $\begin{array}{l}\text { Uncertainty of market. } \\
\text { Market depending upon the middlemen and determination of } \\
\text { the market price by them. } \\
\text { Frequent fluctuation of vegetable price. } \\
\text { Lack of concern in market from the local government. }\end{array}$ \\
\hline $\begin{array}{l}\text { Seed and fertilizer } \\
\text { related problems }\end{array}$ & $\begin{array}{l}\square \\
\square \\
\square\end{array}$ & $\begin{array}{l}\text { Lack of proper knowledge to produce seed of all kinds of } \\
\text { vegetable. } \\
\text { Lack of distribution of adequate seeds by the concern agencies. } \\
\text { Unavailability of improved qualitative seed. } \\
\text { Unavailability of qualitative fertilizer in local market. }\end{array}$ \\
\hline $\begin{array}{l}\begin{array}{l}\text { Labor related } \\
\text { problems }\end{array} \\
\end{array}$ & $\square$ & Difficulty to find sufficient and skilful labour in local area. \\
\hline $\begin{array}{l}\text { Productivity } \\
\text { diminishing }\end{array}$ & $\begin{array}{l}\square \\
\square \\
\square \\
\square\end{array}$ & $\begin{array}{l}\text { Imbalance use of chemical fertilizer productivity decrease. } \\
\text { Productivity decrement by top soil erosion, gully erosion etc. } \\
\text { Lack of sufficient extra land for rotation farming for some } \\
\text { farmers. }\end{array}$ \\
\hline
\end{tabular}




\section{Expectation of the commercial vegetable farmers}

Commercial agriculture is a major characteristic of Chhathar Jorpati rural municipality as such there is necessary to promote and motivate the farmer for their contribution. Nevertheless, agriculture friendly economic policy and effective implementation is required from government sector to promote it. Sustainable economic growth can be achieved through agriculture development avoiding deforestation, and land degradation. Therefore, the government should make the policy of local governance effectively both in terms of strategy and implementation aspects (Chaudhary, 2018). It would be better if the government would undertake responsibility to marketing of the product. It is necessary to develop agro tourism to the area so that they could get double benefit. The farmers want to get new innovation training about how to do more profitable farming and how to use new technology in this field.

\section{Conclusion}

Farming in Nepal is labor intensive and it is mainly based on family labor. From the beginning of human civilization, agriculture has been the main source of people's livelihood. Vegetable farming is a traditional custom in the Nepalese community, particularly for culinary purpose. Being an economic activity, it is closely related to the livelihood, employment and semi-employment. The present work has attempted to explore and analyze the socio-economic condition of vegetable farmers of Chhathar Jorpati rural municipality area and impacts of vegetable farming on their livelihood. The majority of farmers cultivate high valued vegetables such as cauliflower, cabbage, tomato, pea, radish, carrot and green leafy vegetables. Better utilization of available resources in the area, establishment of cooperatives to support it and good transportation facility help in flourishing the vegetable farming. However, awareness program is urgently necessary to control improper use and handling of chemical fertilizer and pesticides for the enhancement of vegetable farming and fertility of the soil in the area.

\section{Acknowledgements}

We are thankful to all the field enumerators for their help during field survey. Special thank goes to all the farmers who provided their valuable time to share local knowledge on this study. We extend our sincere gratitude to the editors and anonymous reviewers for their valuable comments on our paper. 


\section{References}

Amatya, S. L. (1975). Cash crop farming in Nepal. Kathmandu: Ratna Pustak Bhandar.

Bishop, B. C. (1990). Karnali under stress: Livelihood strategies and seasonal rhythms in a changing Nepal Himalaya. Illinois: University of Chicago.

Bhatta, G. D., \& Doppler, W. (2010). Socio-economic and environmental aspect of farming practice in the peri-urban hinter land of Nepal. The Journal of Agriculture and Environment 1 (11): 26-39.

Carney, D. (1998). Sustainable rural livelihoods: What contributions can we make? London: DFID.

CASA, (2020). Vegetable sector strategy - Nepal. Commercial Agriculture for Smallholders and Agribusiness. Kathmandu: CASA Nepal Country Team, Nepal

CBS, (2011). National population and housing census 2011. Kathmandu: National Planning Commission Secretariat, Government of Nepal.

Chambers, R. and Conway, G. (1991). Sustainable rural livelihoods: Practical concepts for the $21^{\text {st }}$ century. IDS Discussion Paper 296. University of Sussex: Institute for Development Studies.

Chapagain, P. S. (2006). Involution or evolution? Conceptualizing the changes in farming system of eastern Nepal. The Himalayan Review. xxxvii: 1-17.

Chaudhary, D. (2018). Agricultural policies and rural development in Nepal: An overview. Research Nepal Journal of Development Studies, 1(2): 34-46. https:// dx.doi.org/10.3126/rnjds.v1i2.22425

David R. H. and Dorian Q. F. (2014). Agriculture: Definition and overview, University College London State of Knowledge and Current Debates.https://www. researchgate.net/publication/301345493

Ellis, J. (1999). Poverty, land care and sustainable livelihood in Hillside and Mountain regions. Mountain Research and Development, 19(3): 179-190.

Fararo, T. J. (2007). Encyclopedia of law \& society: American and global perspectives social status. Sage Publications Thousand Oaks. http://dx.doi. org/10.4135/9781412952637.n637 
Kishor Bhandari, and Basanta Paudel/ Impact of vegetable farming ...Vol. 14: 131-150, 2021

GA.(2019).Industrial agriculture and small-scale farming. Global Agriculture: Foundation on Future Farming. Marienstr. 19-20 D-10117 Berlin, German.

Gahatraj, S. Rai, H. H., \& Uprety, R. (2019). Assessment of contribution of cabbage in rural livelihood and constraints of production in Dhankuta, Nepal. International Journal of Agriculture, Environment and Food Science, 3(3): 150-154.https:// dx.doi.org/10.31015/jaefs.2019.3.6

Gahatraj, S. and Uprety, R. (2019). Financial profitability and resource productivity analysis of garden pea (Pisum Sativum L.) production in Dhankuta, Nepal. SAARC J. Agric., 17 (2): 165-172. https://doi.org/10.3329/sja.v17i2.45303

Ganesan, L. and Karuppaiyan, K. P. (2017). Utilization of agriculture input and it's outcome in Indian agriculture. Shanlax International Journal of Economics, 5(4): 65-79.

Gauchan, D. (2008). Agricultural development in Nepal: Contribution to economic growth, food security and poverty reduction. Socio Economic Development Panorama, 1 (3): 49-64

Giller, K. (2014). Guest editorial can we define the term 'farming systems'? A question of scale. Outlook on agriculture, 42(3): 149-153.https://dx.doi.org10.5367/ oa.2013.0139

Gurung, B., Thapa R. B., Gautam, D. M., Karki, K. B., \&Regmi, P.P.(2016). Commercial vegetable farming: an approach for poverty reduction in Nepal. Agronomy Journal of Nepal, 4: 92-106.

Karkee, A., Timila, R. D., Paudel, K. \& Mandal, D. L. (2016). Current status and management practice of clubroot (Plasmodiophorabrassicae) Disease in Eastern Hills of Nepal. Journal of Environment Science, 2: 121-129. https:// www.researchgate.net/publication/329640980

Khanal, S., Acharya, A. K. \& Kharal, D. K. (2018). Province - 1, Dhankuta Chhathar Jorpati Rural Municipality. https://www.researchgate.net/ publication $/ 325542516$

Koirala, H. L. (2006). Livelihood pattern, adaptive strategy and sustainability of communities in southern Arun valley of Nepal. Unpublished Ph.D. Thesis: Gauhati University. 
Mckenzie, S. (2005). A brief history of agriculture and food production: The rise of industrial agriculture: Johns Hopkins Bloomberg: School of Public Health.

Mlozi, M.R.S. (2003). Urban Agriculture: Vegetable production in Metropolitan Greater Vancouver District in Lanans Sokoine University of Agriculture Morogoro, Tanzania.

MOF. (2019). Economic survey 2018/19. Kathmandu: Government of Nepal, Ministry of Finance.

NPC. (2019). Fifteenth plan 2076/77-2080/81. Kathmandu: National Planning Commission, Nepal.

OECD/FAO. (2019). Agricultural outlook 2019-2028, OECD Publishing, Paris/ Food and Agriculture Organization of the United Nations, Rome. https://doi. org/10.1787/agr_outlook-2019-en

Pandey, G., Basnet, S., Pant, B., Bhattarai, K., Gyawali, B., \& Tiwari, A. (2017). An analysis of vegetables and fruits production scenario in Nepal. Asian Research Journal of Agriculture 6(3): 1-10. https://doi.org/10.9734/ARJA/2017/36442

Paudel, B., Zhang, Y., Yan, J., Rai, R., \& Li, L. (2019). Farmers' perceptions of agricultural land use changes in Nepal and their major drivers. Journal of Environmental Management, 235: 432- 441. https://doi.org/10.1016/j.jenvman.2019.01.091

Pokhrel, D. M. (2010). Comparison of farm production and marketing cost and benefit among selected vegetable pockets in Nepal. The Journal of Agriculture and Environment, 11: 10-25

Rai, D. B. (2017). Vegetable gardening and marketing in Kirtipur area of Kathmandu. Nepalese Journal of Development and Rural Studies, 14 (1\&2):28-35. DOI: $10.3126 /$ njdrs.v14i1-2.19645

Rai, M. K., Paudel, B., Zhang, Y., Khanal, N. R., Nepal, P., \& Koirala, H. L. (2019a). Vegetable farming and farmers' livelihood: Insights from Kathmandu Valley, Nepal. Sustainability, 11(3): 889. https://doi.org/10.3390/su11030889

Rai, M. K., Nepal, P., Rai, D. B., \& Paudel B (2019b). Commercial vegetable farming: Constraints and opportunities of farmers in Kirtipur, Nepal. The Geographical Journal of Nepal, 12: 101-118.http://dx.doi.org/10.3126/gjn.v12i1.23418 
Kishor Bhandari, and Basanta Paudel/ Impact of vegetable farming ...Vol. 14: 131-150, 2021

Shaner, W.W., Philipp, P.F., and Schmell, W.R. (1981). Farming system research and development : Guideline for developing countries. Colorado, Baulder: West view press.

Shaikh, M. R. (2017). Farming system. Doctoral Seminar: Gauhati University. https:// www.researchgate.net/publication/340429050

Shrestha, S.H. (1975). A review of land use pattern in Nepal. The Himalayan Review, 7. Nepal Geographical Society, Kathmandu, Nepal.

Subedi, B. P. and Pandey, R. (2002). Livelihood strategies of Rai community in Arun valley: Continuity and change. In Vegetation and Society: Their Interaction in the Himalayas. Tribhuvan University, Nepal and University of Bergen, Norway.

Turner, B.L., and Brush, S. B. (1978). Comparative farming system. New York: The Gulford Press.

Uddin, K., Shrestha, H. L., Murthy, M. S. R., Barjracharya, B., Shrestha, B., Gilani, H., Pradhan, S. \& Dangol, B., (2015). Development of 2010 national land cover database for Nepal. J. Environ. Manang. 148: 82-90. https://doi.org/10.1016/j. jenvman.2014.07.047. 